\title{
MEMILIH FIGUR PUBLIK BERKESADARAN GENDER: STUDI JARINGAN PENGGUNAAN TOKOH SELEBRITI UNTUK TEMA 'SETARA' PADA AKUN INSTAGRAM KEMENPPPA
}

\author{
Fitria Angeliqa, Martriana P. Said \\ fitria.angeliqa.17@gmail.com,martrianaps@yahoo.com \\ Fakultas Ilmu Komunikasi, Universitas Pancasila, Jakarta
}

Article Info

Keyword:

network, gender, public figure, equality of women, Instagram.

\begin{abstract}
The government had used convergence media to disseminate policies to obtain useful feedback. The purpose of this study searched the implications of the communication technology in the participation of social media users, Instagram, in its debate with public policies related to the issue of women's equality promoted by the Ministry of PPPA. The results became an evaluation of the institutions in determining the use of celebrities who have a vast network of friends. The issue of government policy did not get an adequate response because of the lack of audience knowledge and their reflection on the topic-and vice versa. This study used the concept of the communication network with a constructivist paradigm. The unit of analysis is text, posting by selected public figures on the 'Setara' issue in the Kemenpppa account. The collecting data technique used a mix-method to obtain completeness - the data analysis technique used quantitative network analysis with UCI-Net and discourse analysis for qualitative. The results showed that public figures could not be sub-groups/betweenness centrality that gaining public participation. The inaccuracy in choosing celebrity figures for disseminating gender awareness caused equality issues, not fulfilling expectations, from secondary data spread of the gender issues to the weak content interaction.
\end{abstract}

Copyright (C) 2020 Interaksi: Jurnal Ilmu Komunikasi. All rights reserved.

\section{PENDAHULUAN}

Digitalisasi media adalah sebuah konsekuensi kemajuan teknologi yang tidak dapat dihindari. Kehadiran teknologi komputer berjaringan memungkinkan kognisi, komunikasi, dan kerjasama terjalin dalam satu perangkat. Ini yang disebut dengan konvergensi media. Perangkat ini mengendalikan produksi, distribusi (komunikasi) dan konsumsi informasi di satu waktu yang sama, menyatukan ruang-ruang privat dan publik, serta meleburkan berbagai peran-peran sosial dalam sebuah platform (Fuchs, 2014, p. 58; Fuchs, 2013, p. 43).

Media baru dan masyarakat seakan memiliki hubungan dialektis yang memberikan dampak positif dan negatif secara bersamaan. Hampir semua konten diproduksi dan direproduksi oleh pribadi maupun institusi dalam akun-akun dengan tujuan mereka masing- masing. Bagi institusi-terutama institusi pemerintahan-akun media sosial tidak hanya digunakan untuk mengingatkan khalayak akan eksistensinya, tetapi juga membangun citra, hingga diseminasi isu-isu atau nilainilai yang menjadi perhatiannya (Criado, SandovalAlmazan, \& Gil-Garcia, 2013). Berbeda dengan model media konvensional yang memberikan 'efek tunda' pada terpaan konten yang disampaikan, media digital yang memiliki visi meringkaskan kendala jarak dan waktu menawarkan percepatan interaksi yang dampaknya langsung dirasakan kedua belah pihak atau lebih, selama pihak-pihak ini saling terhubung.

Dalam konteks pemerintahan, pemanfaatan media sosial juga sudah dijelaskan dalam Buku Seri Literasi Digital (2018) yang dikeluarkan oleh Dirjen Informasi dan Komunikasi Publik Kekominfo Republik Indonesia. Pada artikel tersebut dibahas cara memaksimalkan penggunaan media sosial bagi Lembaga 
Pemerintahan. Dirjen IKP Kekominfo menyebutkan bahwa pentingnya perencanaan dan pengelolaan media sosial yang baik dan terukur, sebagai bentuk representasi dari negara dan organisasi.

Masalah perempuan terutama berkaitan dengan kesetaraan gender adalah isu abadi yang mengisi akun Instragram Kementrian Perlindungan dan Pemberdayaan Perempuan dan Anak (Kemenpppa). Luasnya abstraksi isu kesetaraan ini kemudian juga berkaitan dengan pembagian kerja, akses kesehatan perempuan, hingga kekerasan seksual. Dalam akun Instagram Kemenppa (@kemenpppa), setidaknya muncul mayoritas unggahan yang berkaitan tentang isu kesetaraan gender ini dengan sekitar 200-an likes pada masing-masing tautan tersebut. Unggahan terkait isuisu kesetaraan gender masuk dalam pengelolaan konten yang penting, sehingga perlu memanfaatkan jaringan tokoh selebriti sebagai cara untuk meningkatkan diseminasi isu di kalangan pengguna media sosial.

Dalam terminology jaringan di media online digital, teman bersifat intangible. Ia berada dalam dunia virtual (bukan fisik), namun selalu berada 'dekat' dengan individu. Pola penggunaan media sosial bahkan juga menggambarkan bentuk afirmasi dari orang-orang yang terhubung dengan pengguna media sosial tersebut. Penelitian tentang sosial media analytic juga memperlihatkan efektivitas konten bisnis melalui interaksi antara follower dan akun Instagram produk/jasa melalui like, comment dan share (Alfajri et. al, 2019). Fitur social media analytic digunakan untuk memperlihatkan insight yang mengukur activity, content, dan audience. Hasilnya kemudian dapat dibaca dalam bentuk tabel data fluktuasi akun. Pada penelitian ini pola grafik interaksi akun menjadi aspek utamanya, dan tidak melihat pada analisis jaringan yang terbentuk dari konten yang diunggah.

Selain jaringan sosial, media digital juga membuka peluang munculnya komunitas-komunitas baru yang banyak mengusung semangat pemberdayaan yang seringkali juga dimotori oleh institusi pemerintahan atau kementrian. Komunitas dan institusi kementrian umumnya melakukan usaha partisipatif dalam rangka mengubah kebiasaan-kebiasaan alamiah individu dalam isu-isu sosial yang mereka usung. Hal yang sama pernah pula dilakukan di Parlemen Inggris yang membentuk badan khusus yang menangani dan mempromosikan soal kesetaraan gender (Grace \& Sawer, 2016).

Kampanye kesetaraan gender atau penyadaran atas tindak pelecehan seksual, dan lain-lain adalah tema -tema yang sering diusung oleh institusi Kementrian PPPA yang biasanya diunggah melalui media sosial Instagram. Melalui testimony figur publik yang dipilih, isu sosial didiseminasi melalui jaringan-jaringan sosial yang menghubungkan banyak individu di dalamnya. Di sinilah peran endorser sebagai titik-titik kumpul individu kemudian menjadi penting. Strategi menggunakan endorser yang merupakan figur publik adalah satu aspek kreatif yang digunakan oleh Kementrian PPPA untuk mengkomunikasikan isu kesetaraan gender dengan tema 'Setara'. Bukan hanya 'likes', komentar yang merupakan bentuk respon khalayak juga bermunculan dalam unggahan tersebut, beberapa mendukung, berkomentar netral atau malah bertentangan. Endorser setidaknya menjadi tokoh penting yang dapat mendulang simpati lebih pada tiap unggahan berdasarkan pada jumlah pengikut masing-masing endorser tersebut. Dari sinilah jaringan komunikasi terjalin, dan isu tersosialisasikan dengan luas.

Dalam artikel lain, disebutkan pula bagaimana aspek gender dan sosial kapital yang dimiliki endorser ternyata juga memengaruhi keberhasilan usaha kecil dan menengah (Tata \& Prasad, 2008). Dari pemikiran tersebut, peneliti mengajukan pertanyaan; bagaimana model jaringan komunikasi yang terkait dengan isu kesetaraan perempuan yang menggambarkan partisipasi publik dalam akun Instagram Kemenpppa? Dengan pertanyaan ini, maka tujuan penelitian yang ingin dicapai adalah melihat implikasi penggunaan media sosial dalam akun Instagram pemerintah, terutama untuk topik kesetaraan perempuan yang menggunakan figur publik dalam diseminasinya. Tujuan utama ini dapat tercapai, jika peneliti melakukan beberapa hal berikut terlebih dahulu, yaitu;

1. Identifikasi figur publik yang dapat mendulang partisipasi publik yang paling besar.

2. Identifikasi jaringan yang terbentuk dalam tema 'Setara' di akun Instagram Kemenppa. 


\section{KAJIAN PUSTAKA}

Metodologi

Paradigma yang digunakan dalam penelitian ini adalah paradigma post-positivis, dengan pendekatan kuantitatif dan kualitatif (mix-method). Pendekatan kuantitatif digunakan untuk melihat model jaringan komunikasi yang terbentuk dalam akun Instagram Kemepppa dalam isu kesetaraan perempuan. Sementara pendekatan kualitatif digunakan untuk memperjelas temuan data kuantitatif yang diperoleh sebelumnya. Terutama untuk mendeskripsikan bagaimana isu dapat memiliki keterkaitan dengan khalayak.

Secara kuantitatif dan kualitatif, perangkat analisa teks digunakan sebagai metode pengumpulan data primer pada penelitian ini. Unit analisis sekaligus unit observasi di dalam penelitian ini adalah teks, yaitu akun Instagram @Kemenpppa untuk tema 'Setara' yang setidaknya tayang pada bulan November 2016 hingga Januari 2017. Dalam teks tersebut terlihat empat hal utama dalam teks yang menunjukan tentang wacana tema 'Setara', yaitu: adanya narasi, produser teks (para figur publik), receiver (khalayak yang memberikan likes dan komen dalam akun Instagram Kemepppa), serta waktu temporal selama tema tersebut digunakan.

Dalam pendekatan kuantitatif, data likes dan comments dikoding untuk kemudian diolah dengan perangkat Uci-Net. Data yang telah diolah, menunjukkan sentralitas pada nodes yang mampu mengumpulkan likes dan comments terbanyak. Sentralitas adalah fitur yang dapat dimiliki masing-masing node dalam jaringan hingga tingkat yang lebih besar atau lebih kecil. Artinya, aktor mungkin sangat sentral dalam jaringan atau juga bisa sangat marjinal (Giuffre, 2013, p. 136). Data juga menunjukan tingkatan, dimana beberapa figur publik diharapkan menjadi 'perantara' antara followers dengan akun Kemenpppa. Sedangkan data kualitatif menggunakan analisis isi kualitatif dengan memantau semua konten Instagram dalam akun Kemenpppa yang memuat figur publik yang mengangkat tema 'Setara'.

\section{Kajian Konsep}

Jaringan Komunikasi di Media Digital dan
Partisipasi Publik

Istilah komunikasi dan masyarakat jaringan sebenarnya telah dikenal sejak lama, bahkan sejak umat manusia melakukan komunikasi dengan orang lain, dan membentuk relasi-relasi sosial di dalamnya. Jaringan sosial merupakan serangkaian aktor dan hubungan-hubungan yang terjadi di antara mereka. 'Aktor' di sini merujuk pada entitas sosial apa pun yang terlibat dalam interaksi dengan orang lain, kelompok kecil seperti keluarga, kelompok yang lebih besar seperti organisasi masyarakat, perusahaan atau bahkan negarabangsa. Aktor direpresentasikan sebagai titik atau 'titik' (nodes) jika digambarkan dalam sosiogram. Garis yang menghubungkan para aktor mewakili 'hubungan' mereka, dalam bentuk apa saja. Dua aktor dalam jaringan yang diikat bersama disebut 'dyad' yang merupakan blok bangunan paling dasar dari jaringan (Giuffre, 2013, p. 8).

Tidak dapat dipungkiri, teknologi memang terbukti mewadahi jaringan sosial ini. Sejak tahun 1990an, ketika internet begitu pesat perkembangannya dalam industri teknologi komunikasi, ia banyak memberikan sumbangan besar dalam terbentuknya masyarakat jaringan seperti saat ini. Teknologi memungkinkan informasi diproses dan disebarkan dengan sangat cepat, dari berbagai sumbernya (Castells, 2010, pp. 51-52).

Menurut Diesner (2015) pada dasarnya, data jaringan dapat dikumpulkan atau dibangun dengan dua cara: Pertama, tersedia secara eksplisit. Misalnya, berdasarkan informasi tentang peserta jaringan —individu atau organisasi-yang memiliki simpul-simpul koneksi dengan agen sosial lain yang telah berteman dengan mereka atau yang kontennya pernah mereka komentari atau balas. Dimana konten tersebut sengaja maupun tidak sengaja disebarluaskan oleh anggota jaringan, seperti (mengulang) unggahan dan tweet mereka. Dalam hal ini, media-media sosial seperti Facebook, Twitter, dan YouTube menyediakan ruang untuk konten tersebut, sekaligus memberikan opsi untuk impor data.

Selain menyaring data jaringan dari data teks, media sosial juga memberikan informasi tentang apa yang ditulis atau disebarluaskan. Salah satu keuntungan utama dari mempertimbangkan data teks untuk analisis jaringan adalah bahwa pendekatan ini memungkinkan 
untuk mempelajari interaksi dan evolusi informasi dan jejaring sosial. Ini merupakan bentuk transformatif yang dapat dimainkan oleh bahasa dalam jaringan dan sebaliknya.

Secara keseluruhan, membangun atau meningkatkan data jaringan berdasarkan data teks melibatkan sejumlah besar keputusan yang harus dibuat. Misalnya, cara mengidentifikasi node apa saja yang potensial dan menghubungkannya ke berbagai titik lainnya. Masalahnya di sini adalah bahwa dampak dari pilihanpilihan (nodes) ini pada data relasional jaringan tidak cukup dipahami oleh banyak orang, terutama jika anggota jaringan juga memanfaatkan metode relasi yang berbeda. Padahal dengan cara ini, setidaknya dapat dimanfaatkan untuk mengetahui kasus jaringan rahasia atau bersejarah.

Oleh karena itu, salah satu fitur utama dari interaksi dan partisipasi dalam jaringan sosial adalah konvergensi antara ruang privat dan publik, yang dimanifestasikan dalam hilangnya batas dalam ucapan atau ekspresi pribadi. Setiap komunikasi yang dimediasi melalui jaringan sosial ini berpotensi publik, bersifat abadi dan reproduksibilitasnya terjadi kata demi kata dalam setiap komunikasi online yang bisa keluar dari konteks aslinya. Pesan dapat disebarkan melalui jaringan teman yang saling terkait. Status penerima bisa berubah, dengan memediasi pesan secara terus-menerus ke penerima lain, ke penerima baru, dan bahkan kembali ke pengirim aslinya. Melalui efek multiplikasi, rantai beberapa generasi penerima ini diibaratkan seperti bola salju yang terjadi di media sosial. Dengan cara ini, rantai pengirim-penerima pesan teratifikasi dengan sendirinya (Dynel \& Chovanec, 2015, p. 10).

Hal yang sama diadopsi pula dalam konteks pemerintahan dan pengglangan partisipasi publik. Model pelayanan dan diseminasi kebijakan pemerintahan yang konvensional disebut-sebut telah beralih ke ' $e$ governance' sejak era digital 2.0 (Dadashzadeh, 2010). Di sisi lain, jaringan sosial yang terwadahi dalam jaringan komunikasi digital—terutama media sosial—juga berguna untuk meluaskan sekaligus 'menyatukan' suara publik dalam satu isu. Dengan media sosial yang saling terhubung, warga berbagi informasi, mengemukakan pendapat dan masukan, hingga terlibat dalam pengam- bilan keputusan di tingkat lokal, regional, hingga pusat (Evans-Cowley \& Hollander, 2010). Artikel lain menyebutnya dengan istilah kolaborasi untuk demokratisasi (Brabham, 2009).

Dengan kolaborasi ini, pemerintah daerah dapat memberikan umpan balik dengan segera, timbal balik, serta memungkinkan transparansi data dan informasi terjaga (Gagliardi, et al., 2016). Hal ini tentunya juga dapat menjadi bentuk kontrol sosial warga terhadap kinerja pemerintah (Song \& Lee, 2015). Masalahnya, keterbukaan dan kontrol sosial yang dijalankan publik juga dapat mengarah ke hal-hal yang bersifat sinikal, olok-olok, dan mempermalukan pejabat pemerintahan. Misalnya saja dengan bentuk-bentuk meme yang banyak dibagikan melalui akun-akun warga (Milner, 2013). Alih-alih memberikan masukan, warga lebih aktif mengkritisi pemerintah dengan analogi permainan dalam meme yang terus direproduksi.

\section{TEMUAN DAN DISKUSI}

\section{Gambaran Umum Konten Tema 'Setara' dalam akun@kemenppa}

Tema 'Setara' yang diusung oleh Kementrian Pemberdayaan Perempuan dan Perlindungan Anak (Kemenpppa) menurut Yohana S. Yembise (Menteri PPPA saat itu) adalah sebuah tema tentang kesetaraan gender yang diluncurkan untuk membentuk pola pikir masyarakat terhadap perempuan melalui penggunaan internet, dan dilakukan melalui pendidikan sejak dini. Tema ini kemudian didiseminasikan oleh 30 orang figur publik yang menyampaikan pesan kesetaraan gender menurut versi mereka masing-masing. 'Setara' menjadi tema konten dalam akun@kemenpppa selama periode 3 bulan, sejak November 2016 hingga Januari 2017.

Pemahaman tentang konsep gender dan kesetaraan, setidaknya disampaikan oleh figur publik dalam beberapa pesan tentang pembagian kerja lakilaki dan perempuan, 'isu kodrat' perempuan, pemberdayaan, serta potensi dan peluang yang dapat dilakukan oleh perempuan dan laki-laki. Refleksi pribadi ini setidaknya termuat pada tiga hal, yaitu: narasi teks, gambar/foto, video (audio visual). Narasi teks dan foto setidaknya memberikan gambaran tentang makna kesetaraan gender yang dipahami oleh masing-masing 
figur publik.

\section{Gambaran Umum Figur Publik dalam Tema 'Setara' dalam akun @kemenppa}

Analisis awal dilakukan dengan melihat jumlah 'likes', 'comment', ataupun 'likes-comment' pada masing-masing unggahan. Dari bentuk partisipasi minim tersebut, dapat dilihat figur publik mana saja yang dapat memobilisasi akun-akun followers-nya untuk memberikan dukungan sosial sebagai bentuk partisipasinya. Adapun figur publik terdiri dari laki-laki dan perempuan yang berasal dari berbagai profesi, diantaranya adalah dokter muda, aktor/artis sinetron/fim, artis senior, penyanyi, hingga presenter. Berikut adalah gambaran profesi dan nama figur publik yang mengusung tema 'Setara' di akun @kemenppa;

\begin{tabular}{|l|l|}
\hline Nama Figur Publik & \multicolumn{1}{|c|}{ Kelompok Profesi } \\
\hline 1.Tasya Kamila & Penyanyi dan/atau \\
2.Widi Mulia & artis sinetron/film \\
3.Maudy Ayunda & \\
4.Dira Sugandi & \\
\hline $\begin{array}{l}\text { 1.Ringgo Agus Rah- } \\
\text { man }\end{array}$ & $\begin{array}{l}\text { Aktor/aktris sinetron } \\
\text { dan/atau film }\end{array}$ \\
2.Natasha Rizky & \\
Sabaidieter & \\
3.Ayudia Bing Slamet & \\
4.Herfiza & \\
5.Ricky Harun & \\
6.Carissa Puteri & \\
7.Maya Septha & \\
8.Olivia Jensen & \\
9.Haykal Kamil & \\
10.Alice Norin & \\
11.Michelle Joan & \\
12.Jessica Mila & \\
13.Maudy Koesnadi & \\
14.Dwi sasono & \\
15.Widyawati & \\
16.Lukman Sardi & \\
\hline Alexandra Asmasoe- \\
brata & \\
\hline 1.Zeezee Shahab & \\
2.Astrid Satwika & Prenter TV dadio (dan/atau artis \\
3.Desta & sinetron/film) \\
5.Nycta Gina & \\
\hline Mesty Ariotedjo & Dokter dan model \\
\hline 1.Tantri Namirah & Influencer/fashion \\
3.Ayla Dimitri & \\
\hline
\end{tabular}

Tabel 1. Nama dan Profesi Figur Publik

Masing-masing figur publik yang dipilih tersebut setidaknya melakukan unggahan dalam tiga hingga empat kali konten untuk tema 'Setara' ini. Unggahan mencakup foto dan narasi hingga video yang berisikan pendapat pribadi figur publik mengenai kesetaran perempuan berdasarkan versinya sendiri. Dari tabel di atas terlihat bahwa figur publik yang dipilih lebih banyak bekerja di dunia hiburan/entertainment, meliputi penyanyi dan pemain film atau sinetron. Jikapun mereka berprofesi lain, tetap saja profesi dunia hiburan dilakoni sebagai kerja sambilannya. Pilihan figur dengan pekerjaan ini tentunya bukan tanpa sebab. Memilih figur yang berkenaan dengan dunia hiburan, berarti memilih orang-orang yang telah dikenal dan memiliki basis penggemar (fanbase) - dan tentunya juga followers yang cukup besar. Hal ini memudahkan isu kesetaraan ini tersosialisasikan dengan jangkauan yang lebih luas.

Secara demografis, 30 orang figur publik yang dipilih oleh Kemenpppa dalam meyuarakan pendapat tentang kesetaraan gender ini ternyata didominasi perempuan (24 orang), dan 6 orang sisanya adalah lakilaki. Berdasarkan usia dan pengalaman di dunia kerja, empat orang perempuan dan satu orang laki-laki figur publik adalah artis senior (di atas usia 40tahunan). Sementara sisanya didominasi oleh mereka yang berusia di bawah 40 tahun. Sebaran usia ini tentunya dimaksudkan untuk menjangkau target di semua kalangan usia, terutama para generasi millennial yang menjadi pengguna Instagram sekaligus penggemar figur publik dalam usia yang sebaya. Dengan kata lain, isu kesetaraan ini memang lebih banyak ditujukan bagi mereka yang berusia muda.

Secara keseluruhan, dari unggahan tema 'Setara' yang dilakukan oleh ke-30 figur publik terpilih, ternyata tidak satupun yang mencapai jumlah likes di atas 250. Rata-rata setiap unggahan di tema 'Setara' hanya mencapai 200an likes dengan komentar yang juga minim. Tercatat hanya tiga orang figur publik yang dapat mengumpulkan jumlah likes yang tinggi pada unggahan 'Setara'-nya.

\section{Figur Publik yang Mendapatkan Dukungan Sosial Paling Banyak}

Dari hasil analisis dengan menggunakan perangkat Ucinet, maka didapatkan nilai sentralitas tingkatn tinggi hanya pada tiga figur publik saja. Hal ini menunjukkan 
bahwa tidak satupun dari ketiga puluh figur publik tersebut mampu menjadi 'penghubung' - diistilahkan dengan sentralitas keperantaraan - jaringan pertemanan yang mereka miliki dengan akun Kemenpppa, Gambaran sosiogramnya sebagai berikut;

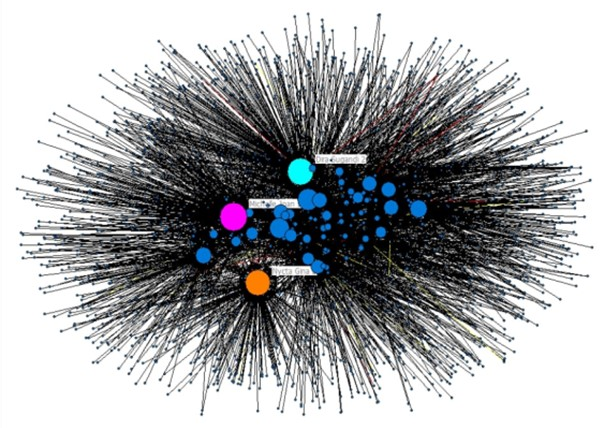

Gambar 1. Figur Publik dengan Dukungan Sosial Paling Banyak (sumber: olahan peneliti, 2019)

Dari sosiogram, terlihat bahwa ada tiga figur publik yang memiliki dukungan sosial berupa rata-rata 200an likes (ditandai oleh garis hitam), comment (menggunakan garis merah), ataupun likes-comment (garis kuning) paling banyak. Data juga menunjukkan bahwa para followers lebih banyak yang hanya memberikan likes, dibandingkan comments, ataupun likescomments. Hal ini terlihat dari tebal-tipisnya garis yang terdapat dalam gambar. Figur publik dengan dukungan sosial paling banyak ini adalah Michelle Joan (penyanyi), Dira Sugandi (penyanyi), dan Nycta Gina (dokter, presenter). Michelle Joan dan Nycta Gina memiliki dukungan sosial paling besar di semua unggahan 'Setara' (versi 1 sampai dengan 3), sedangkan Dira Sugandi hanya mendapatkan banyak dukungan di unggahan kedua dalam narasi foto. Data tersebut juga menggambarkan bahwa Michelle Joan adalah figur publik dengan nilai sentralitas tingkatan tertinggi dari semua pesohor yang digunakan dalam tema 'Setara' ini.

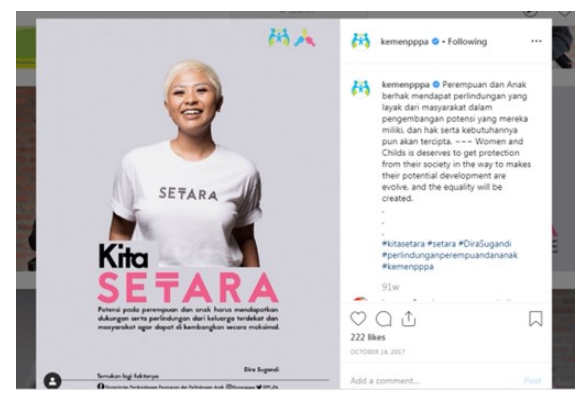

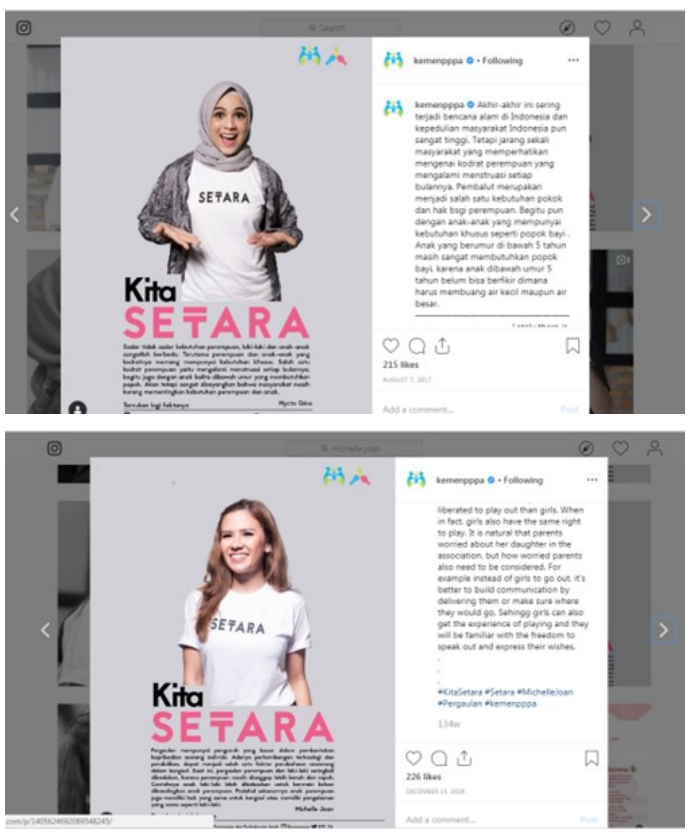

Gambar 2. Tangkapan Layar Figur Publik dengan Dukungan Paling Banyak(Sumber: tangkapan foto akun Instagram Kemenpppa (2018))

Gambaran hasil ini juga menunjukan bahwa dukungan sosial mengerucut pada figur publik perempuan dengan dua orang berusia di bawah 40 tahun, dan satu orang yang tergolong artis senior (40 tahun ke atas). Fakta ini menunjukan bahwa ketertarikan publik ternyata tidak melulu ditentukan oleh usia, tetapi oleh konten yang ditampilkan oleh figur publik tersebut.

Dira Sugandi pada unggahan keduanya menyampaikan tentang pengembangan potensi perempuan dan anak, serta hak yang harus dipenuhi. Berbeda dengan Dira Sugandi, Nycta Gina dan Michelle Joan adalah figur publik yang konstan mendapatkan dukungan sosial besar di setiap unggahan mereka. Di antara tiga tema yang mereka posting, tema kedua tetap yang terfavorit bagi followers kedua figur publik ini. Dalam unggahan kedua ini, Nycta Gina menyampaikan isu tentang penanganan bencana alam yang terkadang kurang memperhatikan kebutuhan spesifik perempuan ketika haid dan kebutuhan diapers untuk anak. Sementara Michele Joan membahas tentang isu pergaulan perempuan dalam ruang lingkup sosial yang sebenarnya memiliki hak yang sama dengan komunitas pergaulan laki-laki, tetapi banyak dikhawatirkan orang tua. 


\section{Figur Publik Laki-laki yang Mendapatkan Dukungan Sosial Paling Banyak}

Data menunjukan bahwa enam orang figur publik laki-laki ternyata tidak cukup menarik minat publik untuk berpartisipasi dalam tema 'Setara' yang dicanangkan Kemenppa. Minimnya jumlah figur publik laki-laki juga menunjukan bahwa tema 'Setara' dalam akun tersebut sejatinya hanya ditujukan untuk target perempuan, dan tidak (perlu) menjadi perhatian lakilaki.

Dari data terlihat bahwa Haykal Kamil yang berusia 28 tahun, menjadi figur publik laki-laki dengan jumlah dukungan sosial terbesar di antara lima orang figur publik laki-laki lainnya. Haykal Kamil yang relatif paling muda ternyata mendulang partisipasi lebih banyak di antara seniornya. Uniknya, hanya akun Haykal Kamil pula yang follower-nya memiliki kaitan dengan follower Jessica Mila—seorang figur publik perempuan yang berusia sebaya dengan Haykal dan ikut menyuarakan tema 'Setara' ini. Dalam data di bawah ini juga terlihat bahwa dukungan publik banyak diberikan pada Haykal di unggahannya yang kedua yang mengangkat tentang perlindungan terhadap perundungan di media sosial.



Gambar 3. Perbandingan Jumlah Dukungan Sosial pada Akun Haykal Kamil(sumber: olahan peneliti, 2019)

Haykal yang merupakan figur publik yang berprofesi sebagai entertainer/pemain sinteron, adalah juga suami dari Tantri Namirah, yang juga ikut dalam kampanye ini. Sama halnya dengan sang suami, Tanti Mirah yang berprofesi sebagai selebgram dan artis sinetron ternyata tidak juga dapat mendulang partisipasi publik yang besar untuk tema tersebut. Setidaknya dari data figur publik yang digunakan Kemenppa untuk menyuarakan tema 'Setara' dalam akun Instagramnya, tercatat ada empat pasangan suami istri lainnya yang terlibat dalam kampanye ini, yaitu Ringgo AgusSabaidieter, Dwi Sasono-Widi Mulia, Desta-Natasha Rizky, serta Lucky Harun-Herfiza. Sama halnya dengan pasangan Haykal-Tantri, pasangan lain juga tidak mampu mendulang partisipasi publik pada konten bertema kesetaraan gender yang mereka sampaikan. Padahal, sebagai pasangan dengan jumlah followers masing-masing yang besar-dan saling terhubungtema kesetaraan ini akan lebih mudah tersebar karena moda keterhubungan di antara akun Instagram pasangan-pasangan ini.

\section{Kerja Jaringan dan Usaha Pemberdayaan dalam Tema 'Setara' di Akun Kemenpppa}

Cara berpikir jaringan adalah meniru cara kerja sistem syaraf manusia yang memiliki keterhubungan, dengan berbagai nodes sebagai simpul kontrolnya. Globalisasi dan masyarakat berjaringan paling mudah dikenali dalam operasional organisasi saat ini. Penempatan unit-unit bisnis dalam industri periklanan, jurnalistik, radio, film, rekaman dan hiburan di berbagai Negara adalah salah satu contoh (Staubhaar, LaRose, \& Davenport, 2012, p. 504) bagaimana industri menerapkan model komunikasi jaringan. Intinya, jaringan komunikasi memungkinkan pemberdayaan setiap titik yang terhubung, untuk berbagai tujuan, seperti komersil hingga diseminasi ideologi.

Pola yang sama setidaknya juga coba diikuti oleh Kementrian Pemberdayaan Perempuan dan Perlindungan Anak (Kemenpppa) dalam mengusung tema 'Setara'. 'Menggerakan' suara publik via figur publik menjadi teknik untuk merebut hati dalam tema tersebut. Figur publik yang memiliki basis penggemar (fanbase), dianalogikan seperti nodes yang dapat saling menghubungkan berbagai suara publik yang tersebar, untuk selanjutnya mengerucut di akun Kemenpppa. Jumlah figur publik yang digunakan pun cukup besar-bahkan sepuluh di antaranya berstatus suami-istri-yang diharapkan mampu menarik perhatian dan dukungan publik yang besar pula berdasarkan jalinan relasi-relasi sosial tersebut.

Sayangnya, data menunjukkan bahwa figur publik yang digunakan dalam tema 'Setara' di akun Kemenpp- 
pa, ternyata tidak mampu mendulang dukungan yang besar dari publik. Hal ini setidaknya terlihat dari temuan tentang jumlah yang minim pemberi 'like' dan 'comment' pada masing-masing unggahan yang dilakukan figur publik pada tema-tema 'Setara' tersebut. Padahal 'like' dan 'comment' adalah respon awal yang dapat menentukan apakah suatu unggahan berhasil menarik perhatian publik ataukah tidak. 'Like' dan 'comment' ini juga menjadi indikasi minim interaksi dan partisipasi yang menjadi ciri utama pengguna media sosial online. Ketika poin ini bernilai rendah, maka beberapa hal dapat menjadi sebabnya, diantaranya;

Pertama, tidak semua figur publik mengaitkan unggahan mereka tentang tema 'Setara' dalam akun Kemenpppa, ke dalam akun pribadi mereka sendiri. Tercatat hanya sebelas orang yang melakukan unggah ulang tema tersebut dalam akunnya dan menyebut (mentioned) akun Kemenpppa. Mereka adalah Ricky Harun, Ayudia Bing Slamet, Sabaidieter, Jessica Mila, Michelle Joan, Alika Islamidina, Maudy Koesnaedi, Vincent Rompies, Naura, dan Ayla Dimitri. Uniknya dari kesebelas figur publik yang melakukan unggahan ulang tema tersebut, hanya Michelle Joan yang masuk dalam kategori figur yang dapat mendulang partisipasi terbesar sebagaimana penjelasan pada bagian sebelumnya. Rendahnya aksi unggah ulang oleh para figur publik ini, menyebabkan isu 'Setara' tidak terdesiminasi secara luas, bahkan tidak juga menjangkau basis followers para pesohor itu sendiri, yang rata-rata memiliki jumlah pengikut di atas seratus ribu akun. Alihalih fanbase adalah modal utama bagi figur publik dalam menarik banyak partisipasi yang berasal dari para pengikut mereka.

Kedua, adanya ketidaksesuaian tema 'Setara' dengan pemikiran followers para figur publik tersebut. Terlebih untuk figur publik yang didominasi oleh generasi millennial dengan basis pengikut dengan usia yang sama pula. Ketidakpahaman tentang konsep gender juga menjadi salah satu poin yang menyebabkan partisipasi publik tidak tertampak. Ketidaksetaraan gender dianggap sesuatu yang 'normal', alih-alih ketidakberesan. Bukan sekedar karena mereka tidak menyukai, tapi lebih karena mereka tidak memahami makna di balik narasi para figur publik tersebut dalam tema kampanye 'Setara'. Hal ini tergambar pada tangkapan layar beberapa pesohor berikut ini;

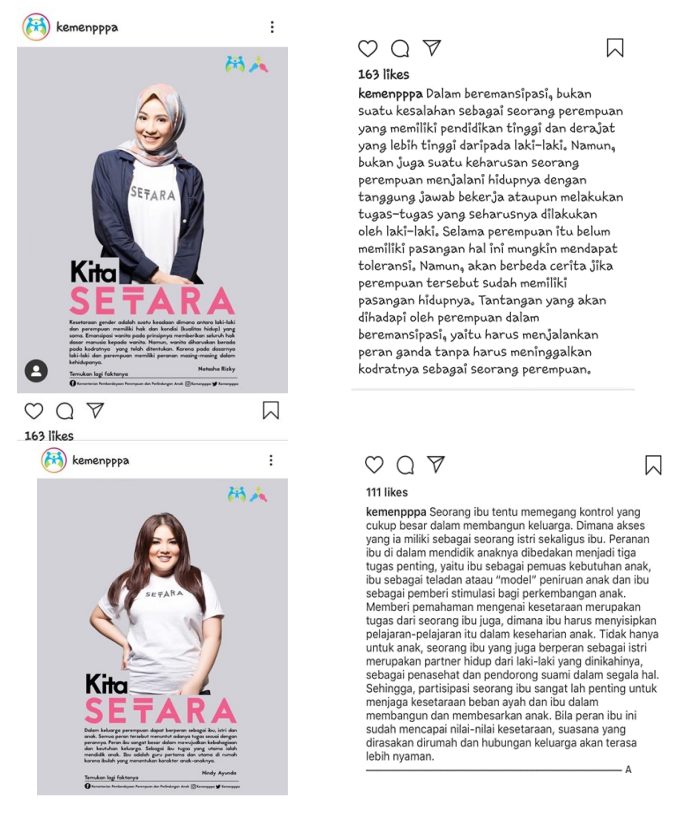

Gambar 4. Tangkapan Layar Figur Publik dengan Narasi Ketidakpahaman Gender (Sumber: Instagram Kemenpppa, 2018)

Dari tangkapan layar kedua figur publik di akun Kemenppa ini, terlihat bagaimana kedua pesohor ini masih memiliki ketidaksadaran gender dalam narasi yang ditulisnya. Sebagai contoh, Natasha Rizky masih menggunakan kata 'peran ganda' sebagai bentuk emansipasi perempuan. Padahal peran ganda merupakan stigma yang menurut Ardaneshwari (2013) dikonstruksi secara universal. Oleh karena itu sebutan superwoman dikenakan kepada perempuan bekerja, sebagai pengganti istilah 'peran ganda' yang lagi-lagi menuntut perempuan yang bekerja di luar rumah untuk tetap menjalankan peran domestik secara sempurna. Sementara figure publik lainnya-Nindy Ayunda-juga menyampaikan hal senada. Ia menggambarkan figur ibu yang memiliki tanggung jawab mendampingi suami sekaligus pendidikan anak di rumah.

Ketiga, konten yang dimuat merupakan tutur sebenarnya dari pendapat para figure publik. Artinya, narasi yang termuat tidak melalui proses editing, sehingga ada ketidaksamaan visi tentang tema 'Setara' antara satu figur publik dengan yang lainnya, maupun dengan Kemenpppa sendiri. Fungsi gatekeeper yang berubah memang menjadi salah satu masalah dalam 
media online. Mereka tidak lagi menjadi 'penjaga' lalulintas pemberitaan, tetapi hanya memastikan bahwa trafik data tetap tinggi sehingga terakumulasi dalam database, untuk dapat dimanfaatkan di kemudian hari (Abidin, 2018, p. 44; Harp \& Bachmann, 2018, p. 188). Akibat lanjutannya adalah tidak adanya evaluasi pada informasi yang muncul. Ini juga menjadi poin yang menarik untuk ditelisik lebih dalam. Tidak dapat dipungkiri, perbedaan ideologi dan pemahaman seringkali menyebabkan orang salah menafsirkan tentang wacana kesetaraan gender dan terkesan bias atau justru 'mendorong' orang untuk lebih terjerat dalam dominasi wacana ketidaksetaraan tersebut.

Temuan penelitian juga menunjukan bahwa hampir tidak ada keterhubungan akun publik pengguna dalam satu unggahan figur publik dengan figur publik lainnya. Ketidakterhubungan ini juga menjadi indikasi bahwa figur publik yang dipilih bukanlah nodes/simpul yang menghubungkan banyak orang, yang berpotensi membentuk jaringan yang semakin luas, selaras dengan jumlah pesohor yang digunakan. Pun demikian konten yang disampaikan para figur publik tersebut juga tidak diunggah ulang oleh para pengikutnya. Ketertarikan pada figur publik secara pribadi ternyata tidak sebanding dengan kemampuan mereka dalam memobilisasi partisipasi, atau mendorong tindakan nyata publik untuk bersepakat pada satu wacana yang sama.

Fakta minimnya dukungan publik yang dijelaskan di atas, menunjukkan bahwa pengertian tentang jaringan tidak mampu dimobilisasi oleh figur-figur publikdari berbagai kelompok usia dan profesi-seperti yang dipilih oleh Kemenpppa. Ketidakmampuan mendulang partisipasi ini bahkan tidak juga dapat dilakukan oleh figur publik yang termasuk dalam kategori generasi milenial -dan generasi-generasi selanjutnya-yan merupakan pengguna terbesar media sosial.

Kepercayaan publik — dalam konteks media sosial Instagram Kemenpppa-ternyata tidak pada sosok, tetapi pada konten. Sayangnya, informasi tentang alasan ketidaktertarikan publik bukanlah poin utama yang ingin digali dalam penelitian ini. Banyaknya variasi umur dan profesi jumlah figur publik yang direkrut, sebenarnya bisa menjadi salah satu strategi 'memerangkap' publik dengan tema yang sama.
Dengan tema yang simultan, diharapkan publik di lini manapun dapat menerima pesan yang sama dan dalam periode yang tetap. Bagian ini setidaknya ditunjukkan oleh tema 'Setara' yang dipartisi dalam tiga sub-tema bagi masing-masing publik figur.

Dalam perspektif jaringan, 'tokoh' atau 'sosok' hanyalah 'alat'. Satu tema bisa menjadi efektif, jika memang kesepakatan atas norma dan nilai dalam jaringan telah terbentuk sebelumnya. Bahkan aktor-aktor dalam kelompok-kelompok yang kohesif dapat mengenakan tekanan pada anggota-anggota kelompok yang dianggap tidak taat pada norma dan aturan tersebut. Dalam ikatan jaringan yang kuat, capaian tujuan komunitas bahkan juga dapat diprediksi (Borgatti, Everett, \& Johnson, 2013, p. 194).

Barangkali strategi inilah yang ingin diadopsi oleh akun Kemenpppa, yaitu dengan mengandalkan basis pengikut dari masing-masing figur publik yang terpilih. Dengan cara ini, akun Kemenpppa berlaku sebagai 'pusat' sementara figur publik sebagai sebagai subgroup (nodes). Masalahnya, banyaknya varianusia, jenis kelamin, jenis pekerjaan, tingkat pendidikan, keyakinan, pemahaman, dan lain sebagainya-dari figur yang bersangkutan untuk menyuarakan tema 'Setara' justru menyebabkan suara publik tersebar dalam berbagai variasi, tergantung pada 'nilai dan norma' yang dianut oleh tokoh yang mereka ikuti. Terlebih hasil penelitian juga menunjukkan bagaimana hanya satu dari 30 orang figur publik yang berperan sebagai sentral, dan satu orang lainnya sebagai link yang menghubungkan seorang follower dengan akun figur publik lainnya.

Dalam hal ini Kemenpppa melupakan satu hal penting dalam studi jaringan - baik jaringan komunikasi maupun sosial—bahwa tidak semua tokoh yang direkrut memiliki nilai dan pemahaman yang sama dengan wacana yang digaungkan oleh Kemenpppa. Bagaimanapun gender adalah konsep besar dengan berbagai perspektif yang terkait di dalamnya. Pun demikian dengan pemahaman para penganutnya. Dengan demikian, memobilisasi suara publik melalui figur berdasarkan popularitasnya untuk sebuah tema 'Setara' dalam wacana tentang kesetaraan gender, menjadi sebuah kenaifan. Latar belakang dan nilai pribadi 
figur adalah salah satu penyebab utama mengapa partisipasi pada tema ini begitu rendah.

Terlebih dibandingkan akun kementrian lainnya, akun Kemenpppa hanya memiliki 47.000 pengikut, dan mengikuti 42 akun lainnya. Angka ini relatif kecil dibandingkan dengan akun Kementrian Lingkungan Hidup dan Kehutanan (@kementrianlhk) dengan 145.000 pengikut dan mengikuti 218 akun lain. Pun dibandingkan dengan akun Kementrian Kominfo dengan 566.000 pengikut, dan mengikuti 143 akun lain. Atau akun Kementrian Pariwisata dengan 399.000 pengikut dan mengikuti 217 akun lain.

Fakta ini juga menunjukkan bahwa semakin kecil ruang jaringan yang dibuat oleh akun Kementrian, semakin minim pula suara publik yang dapat didulang. Dalam hal ini terlihat bagaimana akun Kemenpppa pun tidak mengikuti akun-akun lainnya yang berelasi langsung maupun tidak langsung dengannya. Sempitnya ruang pertemanan ini tentunya mengurangi kemungkinan suatu isu terdeseminasi dengan baik.

Sebagaimana disebutkan dalam bagian sebelumnya, Instagram adalah media sosial yang dimiliki konglomerasi media sosial dunia, Facebook. Sama halnya dengan cara kerja media sosial lainnya, Instagram 'mengaitkan' satu per satu akun hingga membuat rangkaian panjang pertemanan. Bukan itu saja, sistem algoritma dalam media sosial juga dapat membaca pola dan ketertarikan penggunanya, sehingga media sosial dapat memberikan saran akun lain yang sesuai dengan ketertarikan tersebut. Dengan demikian, jaringan pertemanan makin besar, tapi secara bersamaan juga makin spesifik dalam wacana ketertarikannya.

Dalam konteks Instagram, minimnya akun teman-baik pengikut dan yang diikuti-akun Kemepppa juga menurunkan popularitas si pemilik akun tersebut. Bagaimanapun Instagram adalah satu media sosial yang menawarkan layanan 'visual' dengan narasi bagi penggunanya. Media sosial ini adalah satu platform yang mampu menunjukkan eksistensi pengguna, dan seberapa populernya ia dalam dunia online digital. Maka jika aspek tersebut tidak terpenuhi, pemilik akun harus rela 'tenggelam' dan tidak dikenal di antara berbagai akun lainnya yang lebih menghibur, lebih banyak pengikut, dan lebih sering melakukan ungga- han.

Beruntung, akun Kemenpppa adalah akun mandatory yang memang harus dimiliki hampir semua institusi Negara untuk mendesiminasikan programprogramnya. Dengan demikian, akun jenis ini memang tidak ditujukan untuk monetasi maupun menggalang pengikut. Tidak heran jika unggahanya tidak juga dinarasikan dan dikonsepsikan sebagaimana karakter institusi bersangkutan. Akibatnya-selain tidak populer-program yang dicanangkanpun tidak efektif karena tidak mendapatkan respon yang memadai untuk sebuah institusi yang dibiayai negara.

\section{KESIMPULAN}

Pada akhirnya dari berbagai temuan yang diperoleh peneliti, simpulan yang dapat ditarik antara lain;

1. Kemenpppa merekrut 30 orang sosok figur publik yang mayoritas adalah perempuan, dan hanya enam orang laki-laki. Mereka kebanyakan bekerja di dunia hiburan/keartisan, dengan berbagai rentang usia, untuk menyuarakan tema 'Setara' sebagai upaya menyosialisasikan kesetaraan gender. Dari 30 orang pesohor tersebut, hanya tiga figur publik, yaitu Michele Joan (penyanyi/artis film), Nyctagyna (dokter/presenter), dan Dira Sugandi (penyanyi) yang mampu mendulang partisipasi publik melalui nilai sentralitas tingkatan dalam bentuk komen dan likes.

2. Rendahnya jumlah partisipasi publik, jumlah pengikut, dan akun yang diikuti, menyebabkan jaringan komunikasi yang terbentuk tidak efektif dalam menyuarakan tema 'Setara' di akun Kemenpppa ini. Hal ini menunjukkan bahwa penggunaan figur publik sebagai node, dan akun Kemenpppa sebagai pusat, tidak efektif untuk mendiseminasikan tema 'Setara' tentang kesetaraan gender, karena ketidakterhubungan antar akun followers maupun akun figur publik yang dipilih.

\section{DAFTAR PUSTAKA}

Abidin, C. (2018). Internet Celebrity: Understanding Fame Online. European Journal of Communication, 33 
No. 6, 696-697. https:// doi.org/10.1177/0267323118814646a.

Ardaneshwari, J. (2013, March). Potret Dilema Perempuan Bekerja dalam Media Perempuan Indonesia. Jurnal Perempuan 76, Vol. 18 No. 1, 24.

Brabham, D. C. (2009, July 3). Crowdsourcing the public participation process for planning projects. Planning Theory, Vol. $\quad 8 . \quad$ https:// doi.org/10.1177/1473095209104824.

Borgatti, S. P., Everett, M. G., \& Johnson, J. C. (2013). Analyzing Social Networks. California: SAGE Publications Ltd.

Castells, M. (2010). The Rise of the Network Society, 2nd edition With a New Preface. Sussex: Blackwell Publishing Ltd.

Criado, J. I., Sandoval-Almazan, R., \& Gil-Garcia, J. R. (2013, November 18). Government innovation through social media. Government Information Quarterly, Vol. 30 No. 4, 319-326. https://doi.org/ doi:101016/j.giq.2013.10.003.

Dadashzadeh, M. (2010, November 3). Social Media In Government: From eGovernment To eGovernance. Journal of Business \& Economics Research, Vol. 8 No. 11, 81-86. https://doi.org/10.19030/jber.v8i11.51.

Diesner, J. (2015). Words and Networks: How Reliable Are Network Data Constructed from Text Data? In E. Bertino, \& S. A. Matei, Roles, Trust, and Reputation in Social Media Knowledge Markets: Theory and Methods. Springer International Publishing.

Dynel, M., \& Chovanec, J. (2015). Participation in Public and Social Media Interactions. Pragmatics \& Beyond New Series 256.

Evans-Cowley, J., \& Hollander, J. (2010, June). The New Generation of Public Participation: Internet-based Participation Tools. Planning Practice \& Research, Vol 25 No. 3, 397-408. https:// doi.org/10.1080/02697459.2010503432.

Fuchs, C. (2013). Social Media: A Critical Introduction. Los Angeles: Sage Publications Ltd.

. (2014). Critique of the Political Economy of Informational Capitalism and Social Media. In C. F.
Sandoval, Critique, Social Media and Information Society. New York: Routledge.

Grace, J., \& Sawer, M. (2016, March 3). Representing Gender Equality: Specialised Parliamentary Bodies. Parliamentary Affairs, Vol. 69 No. 4, 745-747. https:// doi.org/10.1093/pa/gsw004.

Gagliardi, D., Schina, L., Sarcinella, M. L., Mangialardi, G., Niglia, F., \& Corallo, A. (2016). Information and communication technologies and public participation: interactive maps and value added for citizens. Government Information Quarterly, Vol. 34 No. 1, 153 -166. https://doi.org/10.1016/j.giq.2016.09.002.

Giuffre, K. (2013). Communities and Networks: Using Social Network Analysis to Rethink Urban and Community Studies. Cambridge: Polity Press.

Harp, D., \& Bachmann, I. (2018). Gender and the Mediated Political Sphere from a Feminist Theory Lens. In D. Harp, J. Loke, \& I. Bachmann, Feminist Approaches to Media Theory and Research. Switzerland: Springer International Publishing, Palgrave Macmillan.

Kementrian Kominfo Republik Indonesia. (2018). Buku Seri Literasi Digital, 2018, Memaksikmalkan Penggunaan Media Sosial Dalam Lembaga Negara, Direktorat Jenderal Informasi dan Komunikasi Publik Kementrian Kominfo Republik Indonesia, ISBN: 978623-90126-0-1.

M. Alfajri, V. Adhiazni, and Q. Aini. (2019). Pemanfaatan Social Media Analytic Pada Instagram Dalam Peningkatan Interaksi: Jurnal Ilmu Komunikasi, Vol. 8 No. 1, 41-51. https://doi.org/10.14710/interaksi.8.1.3442.

Milner, R. M. (2013). Pop Polyvocality: Internet Memes, Public Participation, and the Occupy Wall Street Movement. International Journal of Communication, Vol. 7, 2357-2390.

Silverblatt, A., Miller, D. C., Smith, J., \& Brown, N. (2014). Media Literacy: Keys to Interpreting Media Messages 4th ed. California: Praeger.

Song, C., \& Lee, J. (2015). Citizens' use of social media in government, perceived transparency, and trust in government. Public Performance \& Management Review, Vol. 39, 430-453. https:// 
doi.org/10.1080/15309576.2015.1108798.

Staubhaar, J., LaRose, R., \& Davenport, L. (2012).

Media Now, Understanding Media, Culture, and Tech-

nology 7th edition. Boston: Wadsworth Cengage

Learning.

Tata, J., \& Prasad, S. (2008, February 5). Social Capital, Collaborative Exchange And Microenterprise Performance: The Role Of Gender. International Journal of Entrepreneurship and Small Business, Vol. 5 No. 3-4.

https://doi.org/10.1504/IJESB.2008.01731. 